PALMER Gus Jr (ed.), 2018, When Dream Bear Sings, Native Literatures of the Southern Plains, University of Nebraska Press, Lincoln, 358 p.

\title{
Catharine Mason
}

\section{(2) OpenEdition \\ 1 Journals}

Electronic version

URL: https://journals.openedition.org/clo/6171

DOI: $10.4000 /$ clo.6171

ISSN: 2266-1816

Publisher

INALCO

\section{Printed version}

Date of publication: 18 June 2019

Number of pages: 229-231

ISBN: 978-2-85831-348-8

ISSN: 0396-891X

\section{Electronic reference}

Catharine Mason, "PALmer Gus Jr (ed.), 2018, When Dream Bear Sings, Native Literatures of the Southern Plains, University of Nebraska Press, Lincoln, 358 p.", Cahiers de littérature orale [Online], 85 | 2019,

Online since 19 June 2020, connection on 23 March 2022. URL: http://journals.openedition.org/clo/ 6171 ; DOI: https://doi.org/10.4000/clo.6171

\section{(c) (†) (8)}

Cahiers de littérature orale est mis à disposition selon les termes de la Licence Creative Commons Attribution - Pas d'Utilisation Commerciale 4.0 International. 


\title{
Palmer Gus Jr (ed.), 2018, When Dream Bear Sings, Native Literatures of the Southern Plains, University of Nebraska Press, Lincoln, 358 p.
}

\author{
Catharine MAson \\ Université de Caen Normandie/CRISCO
}

The work under review here provides documentation and valorization of 29 different literary traditions representing 7 language families. When Dream Bear Sings is an anthology of Native North American literatures, edited by Gus Palmer Jr., and published in 2018 by University of Nebraska Press. The subtitle of this work, Native Literatures of the Southern Plains, indicates the geographical areas represented in this rich array of verbal art traditions and historical works.

Among the written and oral discourse genres anthologized, we find the following: traditional tale, myth, historical narrative, tribal history, cultural history, diplomatic letter, written poetry, written short story, and song. Among the interpretive essays serving as introductions to the pieces, we find multiple approaches: ethnohistory, ethnolinguistics, ethnopoetics, literary ethnography (documentation of verbal art culture), literary history (documentation of verbal art practice), and various accounts of language preservation, documentation, and revitalization reflecting indigenous cultural and epistemological practices.

As with all responsible study of literature and the construction of literary canons, the documentation of oral literary traditions and written genres found inside the covers of When Dream Bear Sings has involved a great many minds and voices. One of the achievements of the editor in compiling this collection is to have brought together multiple sources of verbal art performances alongside a handful of written pieces, without obfuscating the human labor and cross-cultural complexities involved in the editorial process. The resulting entextualizations of 
Native American discourses reflect distinct inquiries and methods conducted by family members, collectors, academics, and a slate of "indirect" contributors including ancestors, all of whose names are indexed.

Through introductions and annotations, the collection offers more or less brief studies of the Southern Plains verbal art and historical works anthologized. Among the introductions, some focus on styles and genres while others bring forth ethnohistorical and ethnolinguistic perspectives and problematics. We identify no single theoretical thread or methodological guideline. If the reader expects a homogenous flow of standardised documentation and textual interpretation, or a balance of attention paid to a determined set of equations with regard to each text, she or he will be confounded. However, the heterogeneity of interpretive methods and aims significantly broadens scientific perspectives of multi-cultural and cross-cultural literary studies in a way that single-thread methodologies will never allow.

In addition to bringing a great quantity and variety of ethnographic linguistic data into a single volume, Palmer and his writers have given prominence to the unique interpretation provided by performers, recorders and transcribers, editors, translators and teachers, as well as a background of ancestral voices, amateur collectors of non-tangible cultural materials, ethnographers, ethnohistorians, and other academics. This work demonstrates that, if we are to elevate the literary and historical traditions of indigenous speakers and communities to their rightful place in academic canons, we must also provide scholarly space for indigenous interpretations of these works and the complex dialogism that makes documentation and responsible editing possible.

To my knowledge, Palmer's anthology is the first to systematically document the names of indirect contributors to the safeguarding and scholarly documentation of the selected works. Of the 115 voices that I count in the introductions, approximately 69 are indigenous language speakers and protectors, or have indigenous roots in the languages documented. Several of the writers, for example Vida Woodhull Stabler and Lance Foster have taken great strides to demonstrate the rigorous processes of collecting, interpreting, and entextualizing Native discourse by naming contributors whose work often goes unnoticed in the editorial process. With today's data-centered approach, one may ignoreas we have so long done with Homer, with religious texts, and with all sorts of commercialized folklore collections - the human voices, lives, and labor that go into verbal art production and its editorial valorization. So often, still today, the vast number of voices required to do scientific justice to an isolated trace of a literary heritage remain masked in the academic mission. 
The strength of When Dream Bear Sings is the meticulous attention paid to the interdependent increments of transmission, recontextualization, interpretation, transcription, translation, entextualization, and editing as human and material processes. Palmer and his associates show us that these multi-layered tasks involve family and community dynamics as well as choices of individual contributors, diverging world views, unequal resources for practicing linguistics and publishing literary works, not to mention the impact of forced migrations and deprivation of basic needs: some combination of these problematics unfold across every page of When Dream Bear Sings, not as a single ideologized polemic or scientific problematic, but as the concrete reality of documenting oral literature. For scholars who work in the fields of oral literature documentation and analysis, When Dream Bear Sings will provide the opportunity to rethink the dialogical process of oral literary heritage and to establish new aims for integrating voices in the editorial process as opposed to sacrificing them for the reification of abstract data. Collective hermeneutics will no doubt be the future of vocal and verbal art editing. 